\title{
Highlights from the UNICEF Adolescent Development and Participation baseline study
}

\author{
Sajeda Amin \\ Population Council \\ Ashish Bajracharya \\ Population Council \\ Michelle Chau \\ Mahesh Puri
}

Follow this and additional works at: https://knowledgecommons.popcouncil.org/departments_sbsr-pgy

Part of the Demography, Population, and Ecology Commons, Family, Life Course, and Society Commons, and the International Public Health Commons How does access to this work benefit you? Let us know!

\section{Recommended Citation}

Amin, Sajeda, Ashish Bajracharya, Michelle Chau, and Mahesh Puri. 2014. "Highlights from the UNICEF Adolescent Development and Participation baseline study." New York: Population Council. 


\section{HIGHLIGHTS FROM THE UNICEF ADOLESCENT DEVELOPMENT AND PARTICIPATION BASELINE STUDY}

BY SAJEDA AMIN ${ }^{1}$, ASHISH BAJRACHARYA ${ }^{1}$, MICHELLE CHAU $^{1}$, AND MAHESH PURI ${ }^{2}$

${ }^{1}$ POPULATION COUNCIL, ${ }^{2}$ CREHPA

\section{Background}

Nepal's Adolescent Development and Participation (ADAP) Program aims to ensure the systematic, ethical, meaningful and regular participation of adolescents and focuses on vulnerable and disadvantaged groups. This holistic program aims to empower adolescents, especially girls, to initiate and sustain activities and interventions that create positive transformation in their families, communities, and society and bring about realization of their rights. Three key strategies include: (1) ensuring active and meaningful participation of adolescents, especially girls and the younger age group (10-14 years); (2) ensuring that core interventions address the age, sex, and situational diversity among adolescents, specifically those who are most at-risk and especially vulnerable to HIV and different forms of violence; and (3) generating and sharing evidence including participatory behavioral monitoring and district-level bottleneck analysis.

In collaboration with UNICEF Nepal, the Center for Research on Environment, Health and Population Activities (CREHPA), and Yuwalaya, the Population Council led a study to develop a research design and implement a baseline survey to inform UNICEF's Adolescent Development and Participation program. The primary aim is to inform the program with adequate and scientifically valid data on adolescents aged 10-19 years from the program coverage districts. To accomplish this, the study measured the socio-cultural and behavioral aspects of the lives of Nepali adolescents in 15 districts of the Terai and Far and Mid Western regions in UNICEF's six domains of holistic adolescent development: 1) Education and Skills, 2) Livelihoods and Financial Literacy, 3) Enabling and Protective Environment, 4) Gender Norms and Gender Equity, 5) Health and Healthy Behaviors, and 6) Civic Engagement and Participation.

\section{Methodology}

The baseline survey was designed as a household sample survey of adolescents, both boys and girls aged 10-19 years, in the 15 UNICEF ADAP program coverage districts in two geographically distinct regions of Nepal: the Mid and Far Western region and the Terai. The Population Council led the study and the overall research and instrument design. Fieldwork training, survey tool refinements, sample design, and data collection and management were led by a team of researchers, supervisors, and interviewers at CREHPA.

- The team covered 150 clusters from the 15 districts in two phases beginning in December 2013. Data collection was completed in April 2014.

- The final sample consists of a total of 3,000 adolescents-1,366 boys and 1,634 girls-living in the Terai and Mid and Far Western regions.

Qualitative research on adolescents was conducted by Yuwalaya through 12 participatory group exercises and discussions in three districts, and 96 key stakeholder semi-structured interviews were conducted by CREHPA in all 15 districts to inform programs and policy.

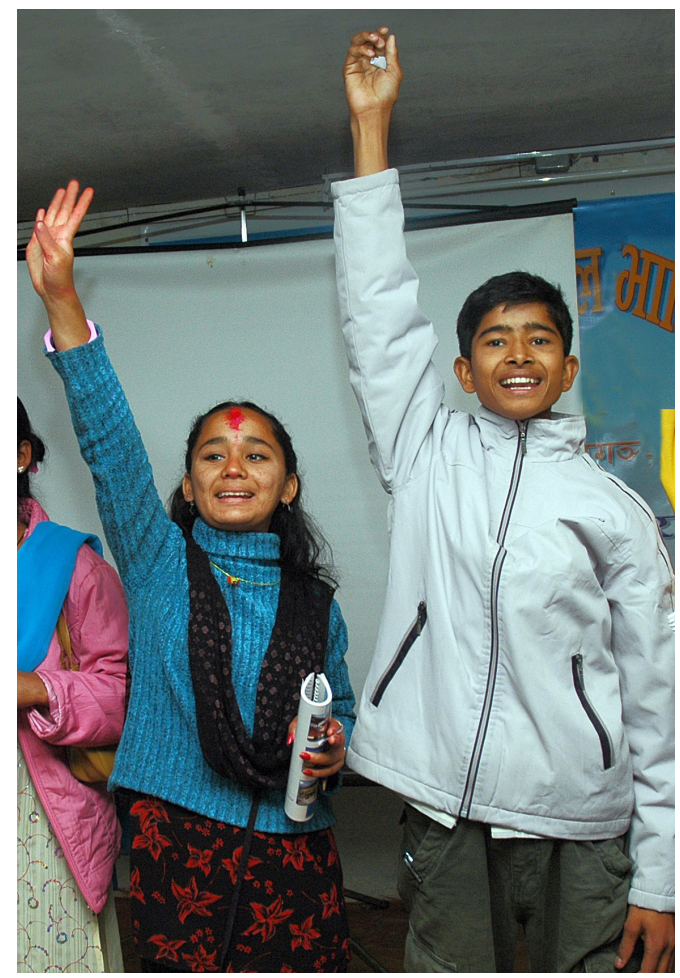

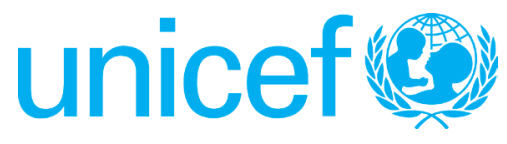




\section{UNICEF focus districts in Nepal}

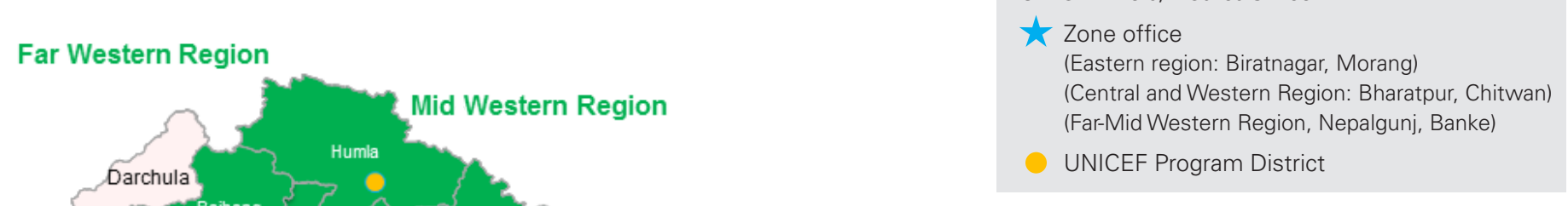

\section{Western Region}

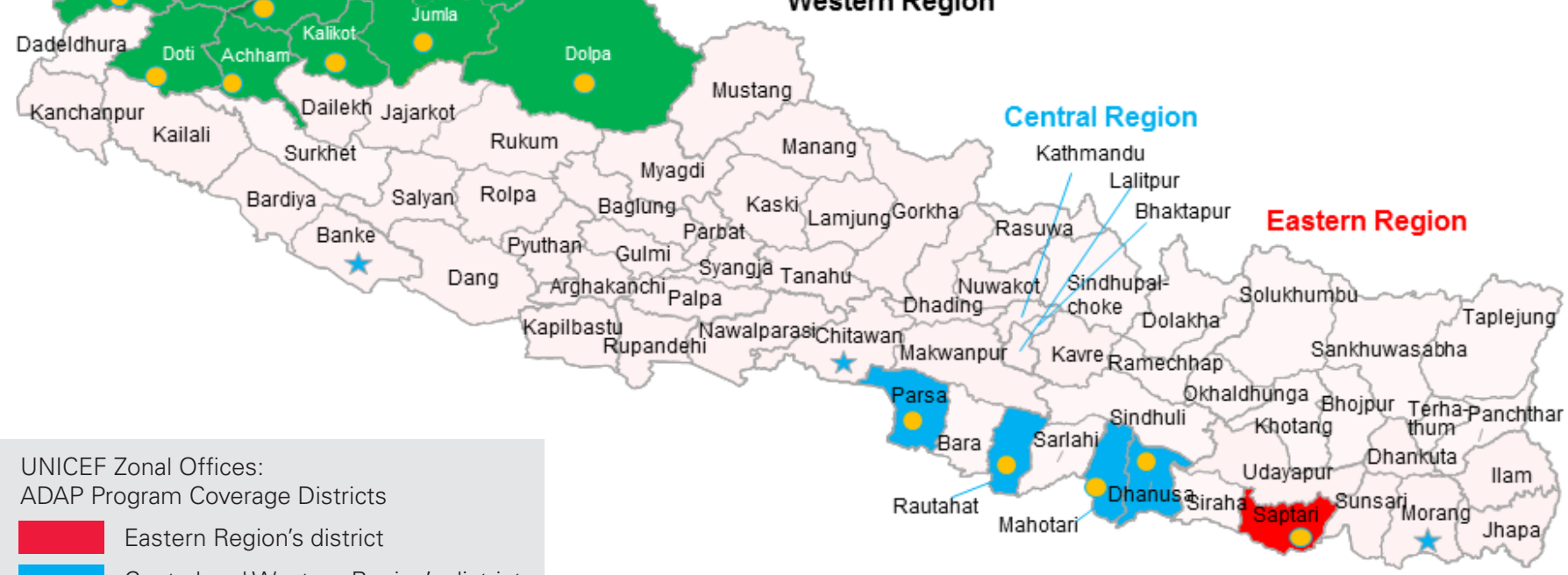

Central and Western Region's district

Far and Mid Western Region's district

UNICEF ADAP PROGRAM COVERAGE AND BASELINE SURVEY DATA

COLLECTION DISTRICTS

\begin{tabular}{lll} 
REGION & DEVELOPMENT ZONE & DISTRICT \\
\hline \multirow{2}{*}{$\begin{array}{l}\text { Far and Mid Western } \\
\text { hilly and mountainous } \\
\text { region }\end{array}$} & Far Western & Baitadi \\
& Bajhang \\
& Bajura \\
& Achham \\
& Doti \\
\cline { 2 - 3 } & Mumla \\
& Mid Western & Kalikot \\
& Jumla \\
& Mugu \\
& Dolpa \\
\hline Terai plains & Parsa \\
& Rautahat \\
& Mahotari \\
& Dentral & Sanusa \\
\hline & Saptari \\
\cline { 2 - 3 } & Eastern & \\
& &
\end{tabular}

\section{Characteristics of sample population}

\section{ETHNICITY}

Adolescents reported belonging to over 50 different ethnic groups.

The dominant ethnicity in the Mid and Far Western regions is

Chhetri. The Terai is more diverse with a larger number of

ethnicities and no one particularly dominant group. The largest

groups are the Yadav and Muslim.

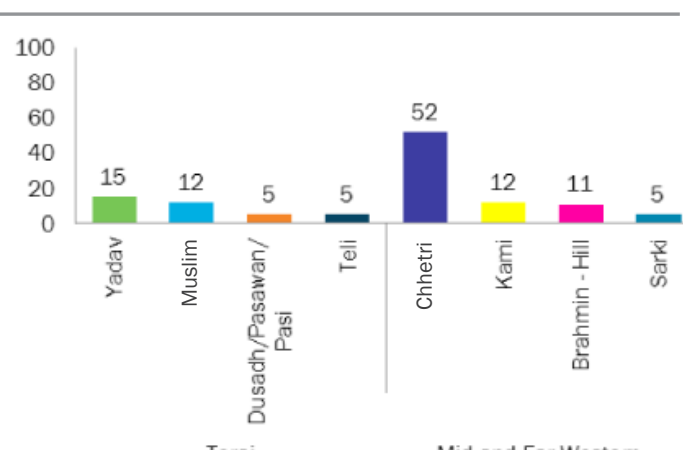

\section{PRIMARY LANGUAGE}

The primary language spoken at home differs by region. In the Far and Mid Western region, the main language is Nepali. In the Terai, it is Maithali.

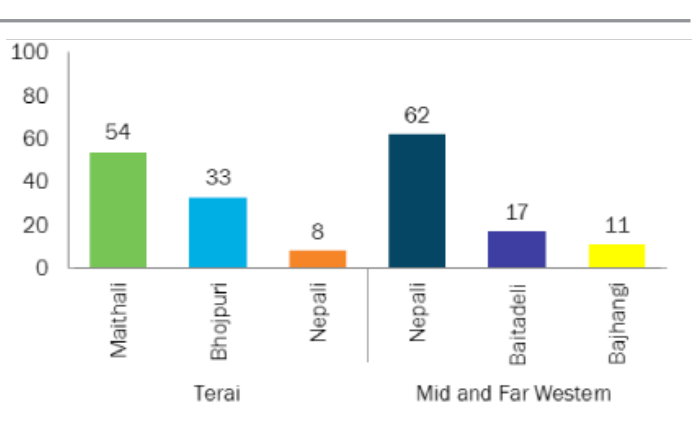

RELIGION

The vast majority of adolescents in program regions are Hindu. In the Terai, $85 \%$ are Hindu but there is a significant Muslim minority. In the Mid and Far Western region, 95\% of adolescents are Hindu.

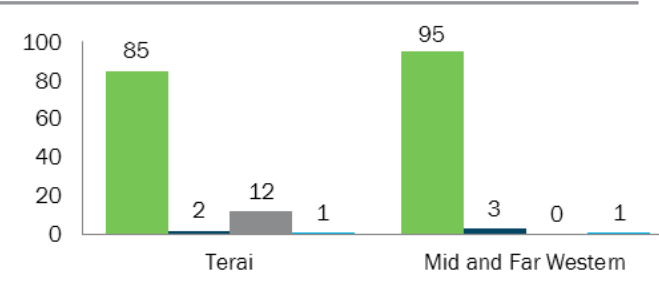
- Hinduism - Buddhism =| Islam =Christianity

\section{PARENTAL EDUCATION}

Educational attainment is increasing among younger generations in ADAP regions. $85 \%$ of mothers and $46 \%$ of fathers have no education. Among adolescents, only $10 \%$ have never attended school.

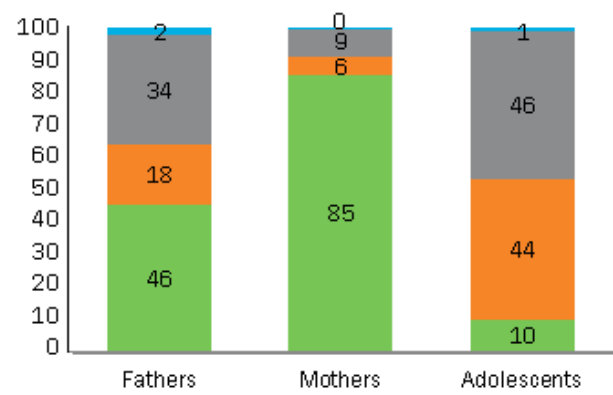

- No education $=$ Primary

\section{HOUSEHOLD ASSETS}

Most households in the Terai have electricity. In contrast, fewer than one in five households in the Mid and Far Western region have electricity.

Mobile phone access is high. $91 \%$ of households in the Terai and $73 \%$ in the Mid and Far Western regions have a mobile phone.

Few households have computers. $5 \%$ of adolescent households in the Terai and only $1 \%$ in the Mid and Far Western region have a computer. Nearly all households in the Mid and Far Western and over half in

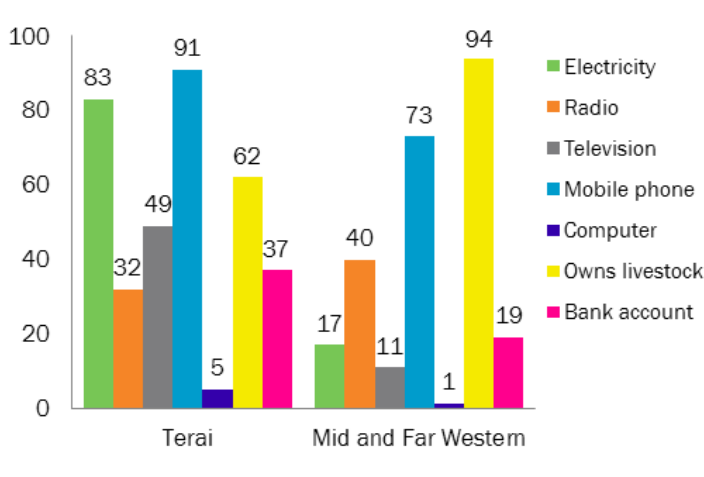
the Terai have livestock or farm animals. 


\section{Education and skills}

ADOLESCENTS OF NEPAL ARE FACED WITH UNPRECEDENTED

OPPORTUNITIES AS WELL AS UNANTICIPATED CONSTRAINTS.

IIII) The ability to attend and complete school and acquire skills can have important implications for healthy and timely transitions to adulthood.

IIII) Getting credentials in schooling as well as age-appropriate skills is a critical part of that healthy transition.

(III) Gender differentials in the experience of and access to school can have important consequences for later life, such as in marriage and childbearing and the abilities to earn a livelihood and to raise healthy children.

\section{SCHOOL ATTENDANCE BY AGE}

Over $90 \%$ of boys and $89 \%$ of girls ever attended school. This is particularly striking given that $85 \%$ of respondents' mothers and $45 \%$ of respondents' fathers have no education, suggesting that opportunities for schooling are relatively recent in the study area. Another indication that schooling is recent is the higher proportion of younger adolescents aged 10-14 who attend school compared to adolescents aged 15-19.

EVER ATTENDED SCHOOL AND LITERACY Schooling rates are higher in the Mid and Far Western region than in the Terai. The literacy gap is even greater with literacy being defined as the ability to read four simple sentences in Nepali.

Four out of five respondents attend government schools Most adolescents report they first attended school whe they were under the age of six. There are no gender or regional differences in this regard
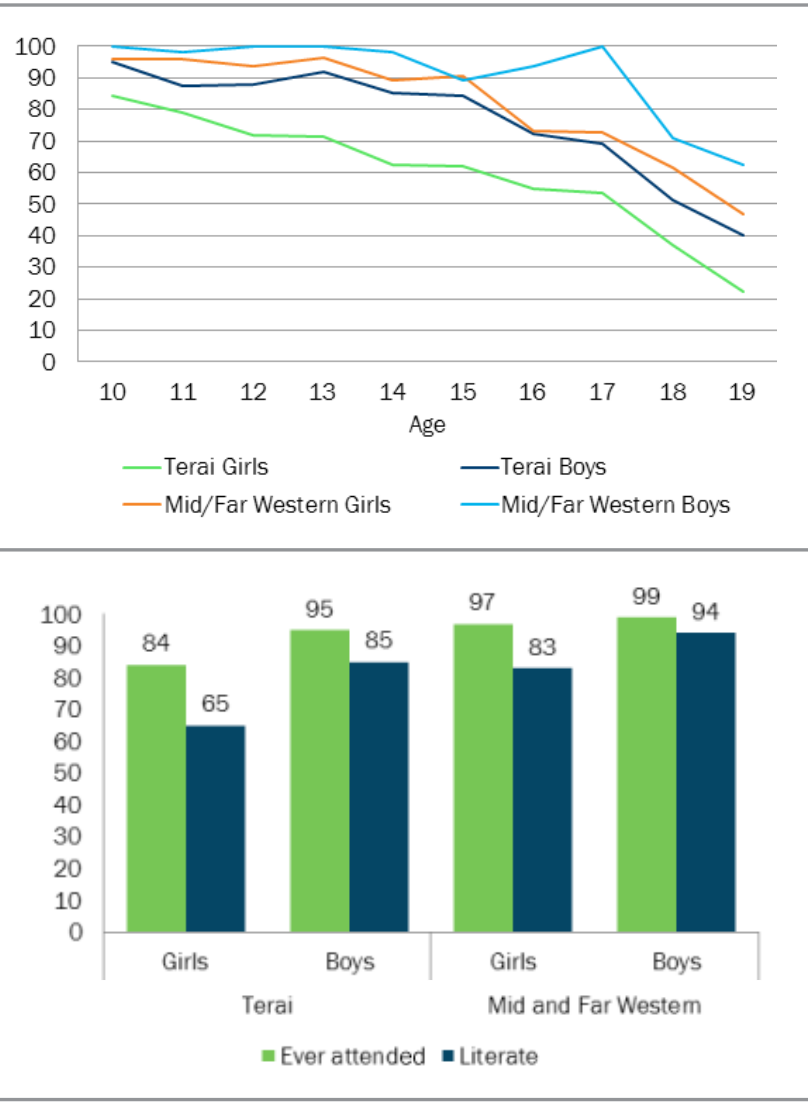

GENDER DIFFERENCES INTUTORING AND STIPENDS

Children receive financial and other support for schooling. Boys are more likely than girls to receive private tutoring but girls are more likely than boys to receive stipend support. $42 \%$ of boys and $37 \%$ of girls who attend school receive private tutoring while $25 \%$ of boys and $69 \%$ of girls received stipend support in primary school. Financial assistance in secondary schoo is much lower- $10 \%$ of boys and $33 \%$ of girls.

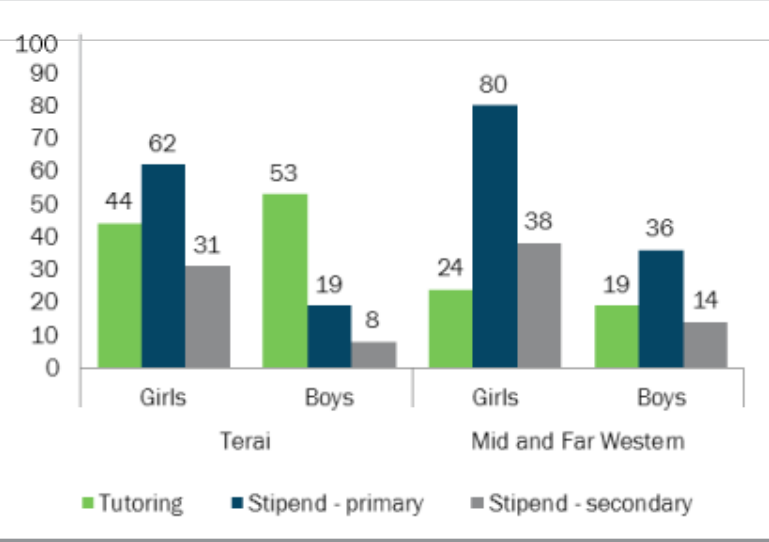

EDUCATIONAL ATTAINIMENT AMONG ADOLESCENTS AGED 15-19

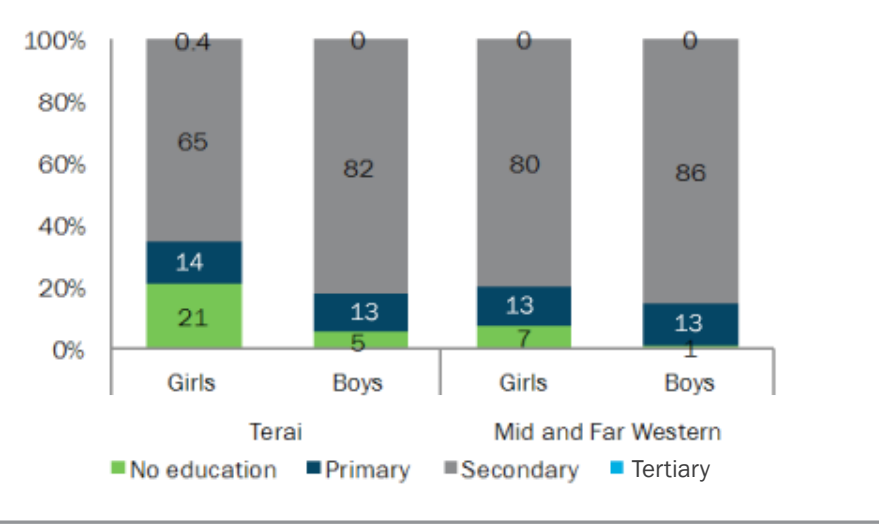

A community leader explained:

CI...Parents are not able to afford books or uniforms for their daughters. Moreover, girls have to do the household chores and cannot balance them with schoolwork...

There is also the possibility of touching others (polluting) during menstruation -this is why they need to stop attending school.

$$
\text { -TEACHER, KALIKOT }
$$

Cf Although we are sent to school, daughters have the burden of household work.

-GIRL GROUP DISCUSSION, AGED 10-14, ACHHAM

\section{CONCLUSION}

Schooling is near universal for boys and girls. The provision of opportunities for schooling is changing rapidly in the Mid and Far West and the Terai. Access to schooling is relatively recent.

\section{HIGHLIGHTS}

- Girls drop out of school at a faster rate than boys despite the fact that they are much more likely than boys to receive stipend support. Efforts at promoting schooling must take into account that most adolescents are the first generation attending school in their families.

- The Mid and Far Western region has more favorable education indicators than the Terai.

- The majority of girls and boys attend school supported by government.
About one in five children attend a rellAbout one in five children attend a relgious or a private institution. Strengthening public provisioning of schools likely to have far-reaching effects.

- Families invest substantial resources in education in the form of private tutoring, and there are important gender differentials in this regard. While boys are more likely to say they quit school because of lack of interest, for girls the

source demands of time and money.

MOST ADOLESCENT GIRLS ARE THE FIRST GENERATION IN SCHOOL

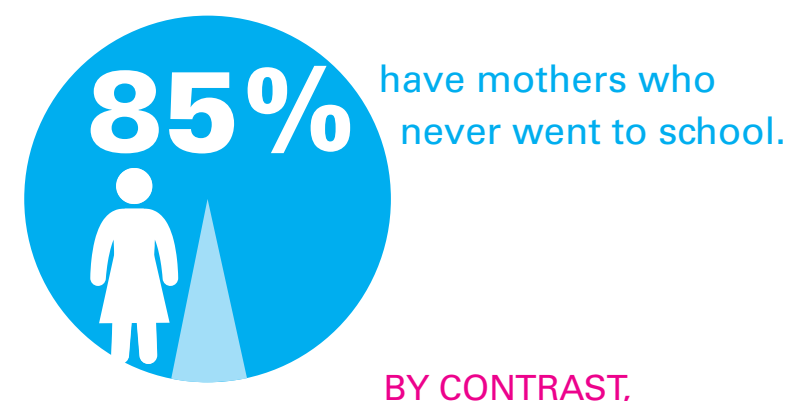

$450 / 0$ of fathers have

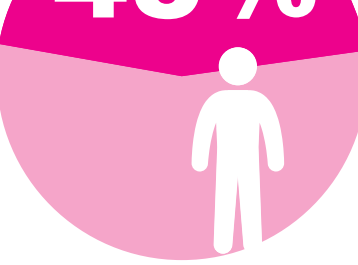




\section{Livelihoods and financial literacy}

FINDING AGE-APPROPRIATE EMPLOYMENT AND HAVING THE RIGHT FINANCIAL SKILLS CAN BE CRITICAL FOR MAKING SUCCESSFULTRANSITIONS TO ADULTHOOD.

mili Young people can acquire important skills during adolescence through engagement in age-appropriate work and financial transactions.

"IiI) A successful transition to adulthood and a safe and productive entry into the world of work can be assured by accessing opportunities to work and saving and borrowing from an early age. Increasingly, migration is linked to accessing these opportunities, and safe mobility is a strong correlate of appropriate timing of workforce entry.

GENDER DIFFERENCES IN WORKFORCE PARTICIPATION, SAVINGS, AND BORROWING Adolescents have opportunities to earn. Boys have more opportunities than girls in our study districts. Most adolescents work as day labor in the agricultural sector. Boys and girls aspire to be teachers, doctors and nurses. More than 50 percent stated such aspirations. The majority of community leader respondents $(80 \%)$ from all three regions thought providing skill-based training and employment opportunities in the locality is an important initiative to benefit adolescents who now have to migrate

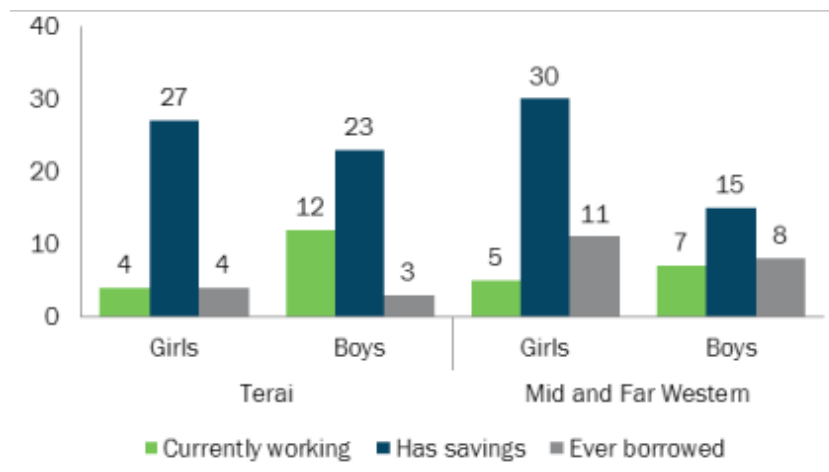

-Currently working - Has savings $=$ Ever borrowed

for work to other areas- $71 \%$ of respondents in the Terai region said that many boys from their areas migrate for work, $62 \%$ responded similarly in the Mid Western region, and $50 \%$ in the Far Western region.

Adolescents engage in saving and borrowing from an early age. Overall $25 \%$ of the respondents said they saved themselves-28\% among girls and $20 \%$ among boys. Less than $2 \%$ saved with a bank.

\section{NEITHER WORIIING NOR IN SCHOOL}

Girls are more likely than boys to be not working and not in school. Girls in the Terai are considerably more likely not to be in school or working compared to girls in the Mid and Far Western region.

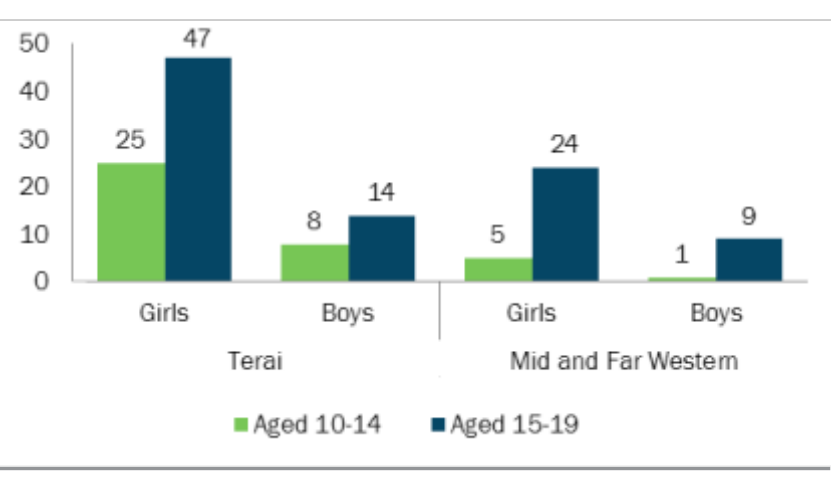

AVERAGE HOURS WORKED IN PAST WEEK Boys work longer hours than girls-36 hours per week on average compared to 25 hours for girls. There is some regional difference, with boys and girls in the Teri having higher levels of workforce participation compared to boys a

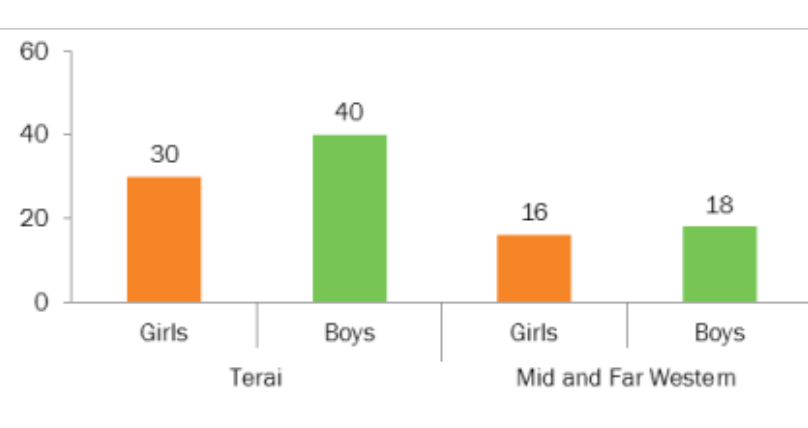

AVERAGE SAVINGS (IN RUPEES)

Girls are more likely to save than boys. They also have more savings

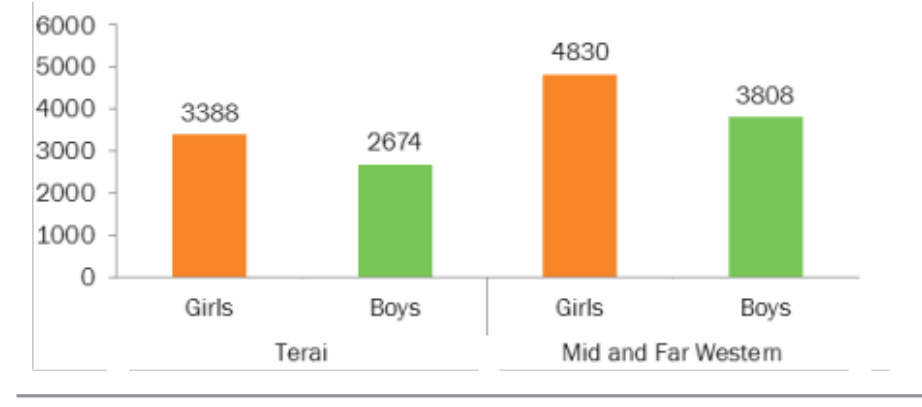

GENDER DIFFERENCES IN KNOWLEDGE OF BANIKING

Knowledge of banking services is higher among adolescents in the Mid and Far Western region. 80

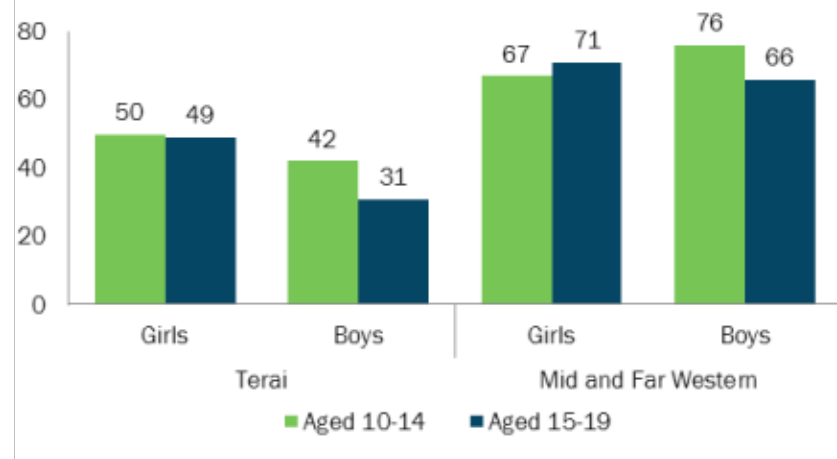

When asked about adolescent work, a community leader explained:

6 The main reason is poverty. Adolescents have to work to earn money due to poor economic conditions of families.

$$
\text { - TECHNICAL ASSISTANT OF VILLAGE }
$$

\section{$1 \mathrm{MY}$}

My parents did not send me to school so that I could help with herding cattle. 5 -GIRL AGED 10-14, ACHHAM

\section{HIGHLIGHTS}

- Adolescents actively seek livelihood opportunities but girls have fewer prospects.

- Although only $7 \%$ of adolescents work, they are active savers and borrowers.

- Girls work 25 hours per week compared to 36 hours for boys. Boys earn twice as much as girls.

$25 \%$ have their own savings. Average savings were NPR 3505 (USD 35). More girls than boys save and girls, on average, have about $50 \%$ more savings than boys.

Although one in four are savers, less than $2 \%$ have a bank account. All the savers save at home, with parents or siblings, or in a piggy bank.

- $8 \%$ of adolescents have borrowed

money and one-third report the loan is interest-bearing

The majority $(43 \%)$ borrowed for educational purposes.

- Financial literacy as assessed by knowledge of financial planning and budgeting and functioning of banks is generally poor.

CURRENTLY WORKINGTO EARN MONEY

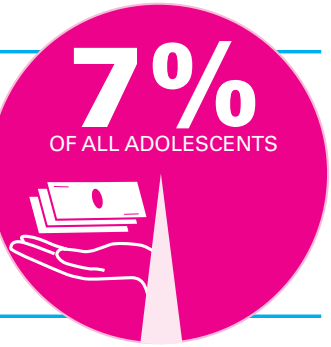

\section{CONCLUSION}

Adolescents use a variety of livelihood strategies which, depending on the opportunities available, may include workforce participation, household subsistence activities, or financial activities (saving and borrowing). Qualitative evidence suggests that livelihoods participation is not only linked to poverty reduction but may also contribute to positive social development by keeping adolescents positively engaged. 


\section{Enabling and protective environment}

ADOLESCENT OUTCOMES ARE SHAPED BY A NUMBER OF CHARACTERISTICS OF THEIR ENVIRONMENT INTERMS OF SOCIETAL NORMIS AND STRUCTURES.

mini Marriage occurs at an early age for girls. Girls' social networks are more limited than that of boys, and norms of violence and dowry strongly disadvantage girls and women.

IIII) Child marriage is far more common among girls than among boys.

MARRIAGE AMONG ADOLESCENTS AGED 15-19

Overall, in our survey sample girls are over four times more likely to be married than boys. A higher proportion of adolescents is married in the Far and Mid Western districts than in the Terai.

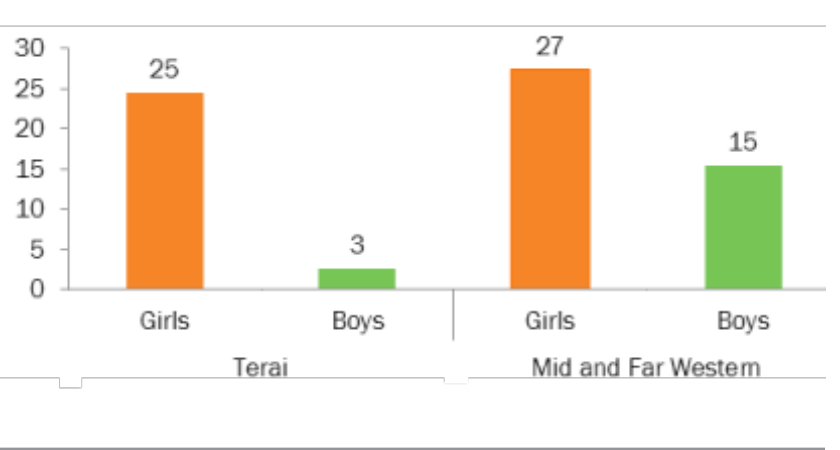

MIARRIAGES WITH DOWRY

Dowry is more often reported by girls than by boys. This is likely because dowry is illegal and received by boys so they are less likely to report it. Dowry is more commonly they are less likely to report it.

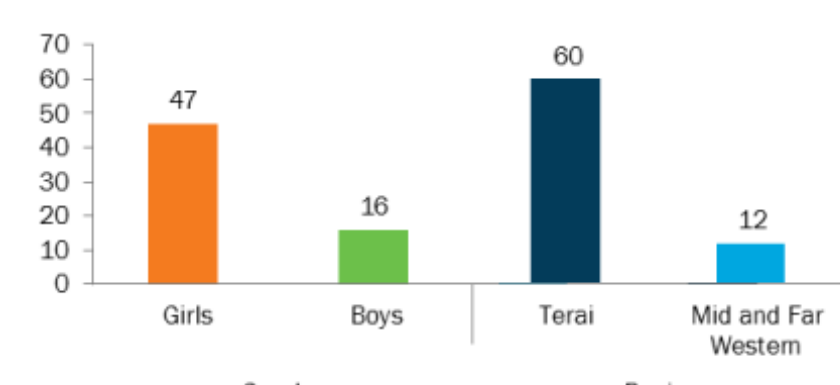

Gender

GENDER DIFFERENCES IN AVERAGE NUMBER OF FRIENDS

Boys have more friends than girls. Older boys have more friends than younger boys while older girls have fewer friends than younger girls.

Boys are also more likely than girls to have supportive relationships in the community. Boys are more likely to have someone in their community to borrow money from $(71 \%)$ and stay with if they have a problem $(70 \%)$ compared to girls (59\% and $58 \%$ respectively).
GENDER AND KNOWLEDGE ABOUT LAWS

Few boys and girls know the legal minimum age at

marriage for girls and even fewer know minimum age a marriage for boys.

Similarly, few girls and boys are aware of the punishments for child marriage or dowry.

A higher proportion of respondents knew that dowry is illegal and that women are allowed to seek divorce.

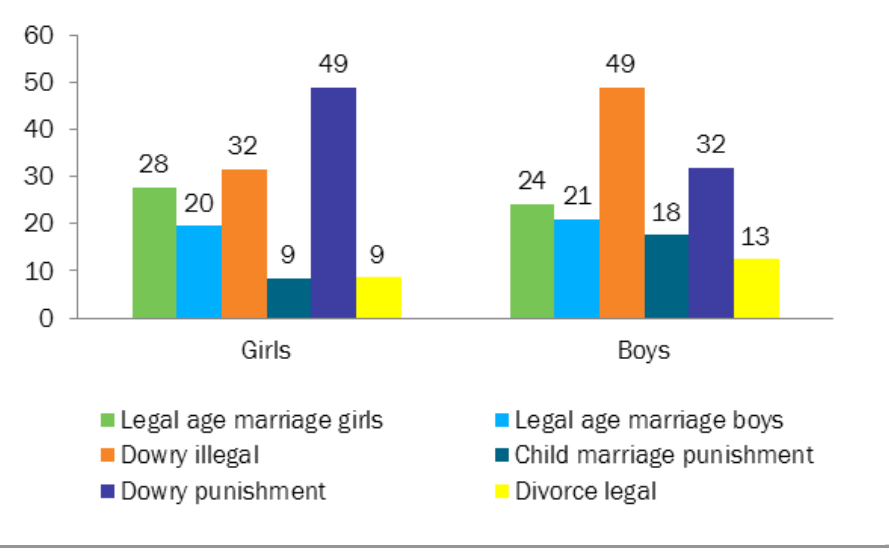

f In our community, daughters are married off at an early age. And if daughters are married off early, parents feel they have to give less dowry. -GIRL GROUP DISCUSSION,
15-19 AGE GROUP, PARSA DISTRICT

\section{CONCLUSION}

Gender norms, attitudes and behaviors show stark differences emerging between girls and boys by late adolescence. Marriage is early and likely an important factor in limiting supportive social networks outside the family, especially for girls. While social networks expand for boys as they grow older, girls see their networks shrink as they get older.

\section{HIGHLIGHTS}

Norms of early marriage and the cultural practice of dowry payments by the bride's family to the groom are important aspects of the normative structure affecting gender differences in the lives of adolescents.

\section{- Girls marry earlier than boys.}

- Girls have more limited social networks of support and fewer friends.

- In general, young people have poor know edge of laws regarding marriage and dowry. Most striking is the lack of knowledge about legal minimum ages at marriage. Poor knowledge about punishments fo Poor knowledge about punishments for child marriage and dowry is underst

able because such laws are not clear.

- Sexual violence is more common than for South Asia in reports of violence. One in six married girls report experiencing

physical violence and nearly one in three

report being forced to have sex by their

husbands.

- Among all adolescents, $45 \%$ report they have a birth registration card. $30 \%$ of ado-

escents aged 16-19 have citizenship cards.

PHYSICAL AND SEXUAL VIOLENCE EXPERIENCED BY CURRENTLY MARRIED GIRLS AGED 15-19

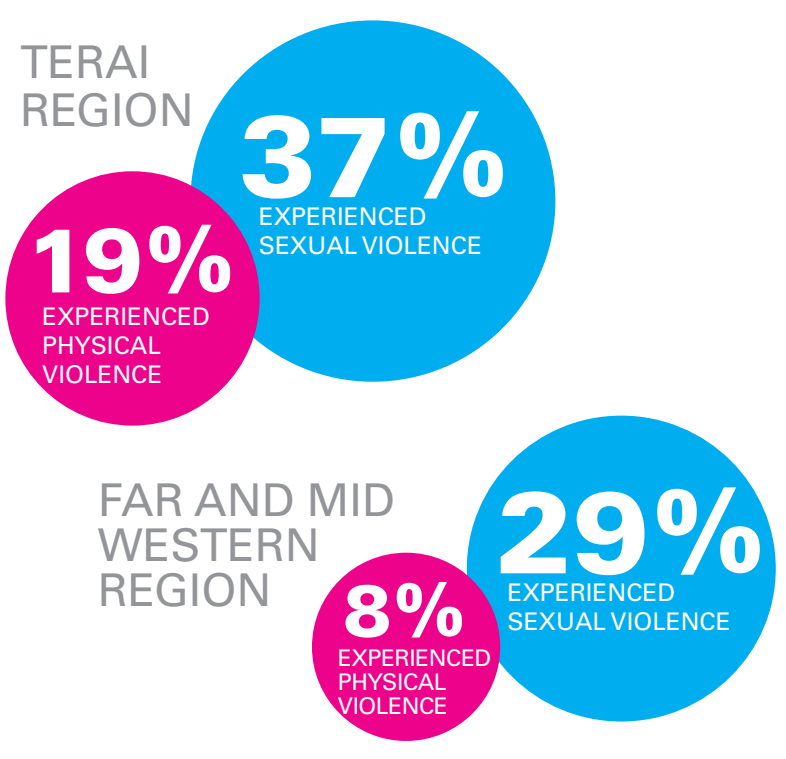




\section{Gender norms and gender equity}

GENDER NORMS AND VALUES ARE FORMED EARLY AND CAN INFLUENCE BEHAVIORS AND OUTCOMES DURING ADOLESCENCE AS WELL AS LATER IN LIFE.

Yiui Young people form their own attitudes about gender equity as well as their opinions about differences between men and women early in life.

IIII) Perceptions of norms and values as well as social practices may limit the choice made by young people with respect to careers, choice of partners, marriage and childbearing

11. Girls are more likely than boys to say they feel discriminated against at home and by their own family than in school. Girls are more likely than boys to say that they have sometimes gone hungry because a sibling of the opposite gender was given food$12 \%$ of girls said they have experienced such circumstances compared to $5 \%$ of boys.

1. Boys and girls are similar in their response in agreeing that "to be a man, you need to be tough," with $45 \%$ agreeing with this statement. Similarly, $64 \%$ of boys and girls believe that men have to fight to defend their reputation.

RIGHTS AND RESPONSIBILITIES

The overwhelming majority of girls (92\%) believe that men and women should be treated the same compared to $80 \%$ among boys. In general, older adolescents are more likely to express such gender-equitable values-93\% among 15-19-year-olds compared to $83 \%$ among 10-14-year-olds. Both boys and girls feel that women should have the right to divorce $-77 \%$ of girls compared to $56 \%$ among boys. Both boys and girls feel that men have a greater right to refuse an arranged marriage compared to women. About $62 \%$ of respondents feel that a woman's most important role is to take care of the home.

GENDER DIFFERENCES IN RIGHTS AND RESPONSIBILITIES

Both boys and girls are more likely to agree that boys can refuse an arranged marriage compared to girls. Nearly $60 \%$ believe boys are allowed to say no to an arranged marriage but only $46 \%$ believe a girl can.

More than three-fourths of older adolescent girls say girls have a right to divorce while among boys only $56 \%$ agree. About one in five women and one in four men believe avoiding pregnancy is solely a woman's responsibility.
PERCEIVING DISCRIIMINATION

Girls are more likely than boys to report they feel discriminated against at home and within their family. They are less likely to feel discrimination at school.

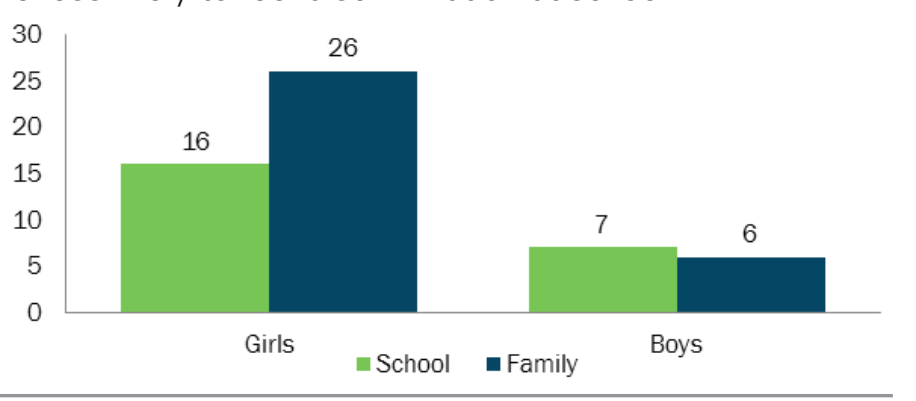

GENDER ROLE ATTITUDES: MACHISIMO Boys and girls similarly agree with statements suggesting hyper-masculine gender roles for men.

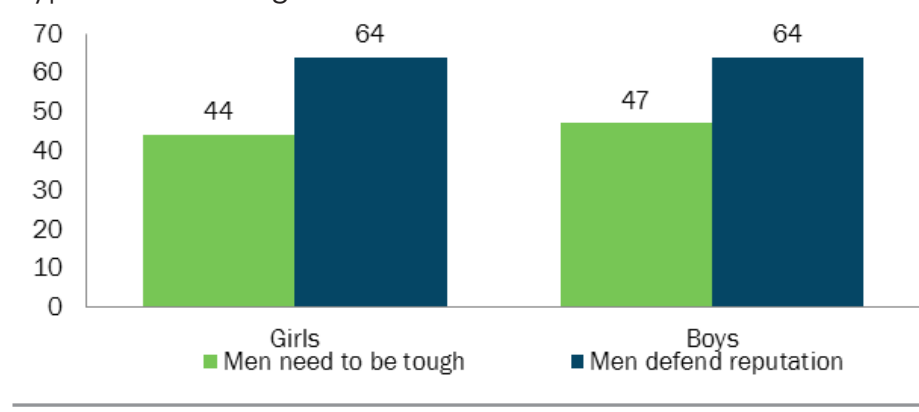

6 While girls are going through their menstrual cycle, they are not allowed to touch food or go in the kitchen. -GIRL AGED 15-19, PARSA

66 My mother made me [only] do chores. But she never asked my brother to do anything.

-GIRL AGED 10-14 (GIRL GROUP

\section{CONCLUSION}

Gender inequitable attitudes are surprisingly high among girls. Although girls are more likely than boys to hold gender equitable values and are more likely to report that they perceive discrimination in the home and at school than boys, a high proportion of girls and boys hold values about masculinity that may encourage violence by men.

\section{HIGHLIGHTS}

Although young people hold values that men and women deserve to be treated

- It is more common to perceive discrimination in the home and family than in school.

Both boys and girls perceive that men more than women are allowed to say no to an arranged marriage.

Boys and girls are equally likely to fee that a woman's most important role is to take care of the home; about two out of three respondents feel this way.

There is little difference between boys and girls in beliefs that may promote men's violence and beliefs that women need to tolerate violence and be subject to violence as sanctions or disciplinary behavior

When asked whether women should tolerate violence in order to keep harmony in the family:

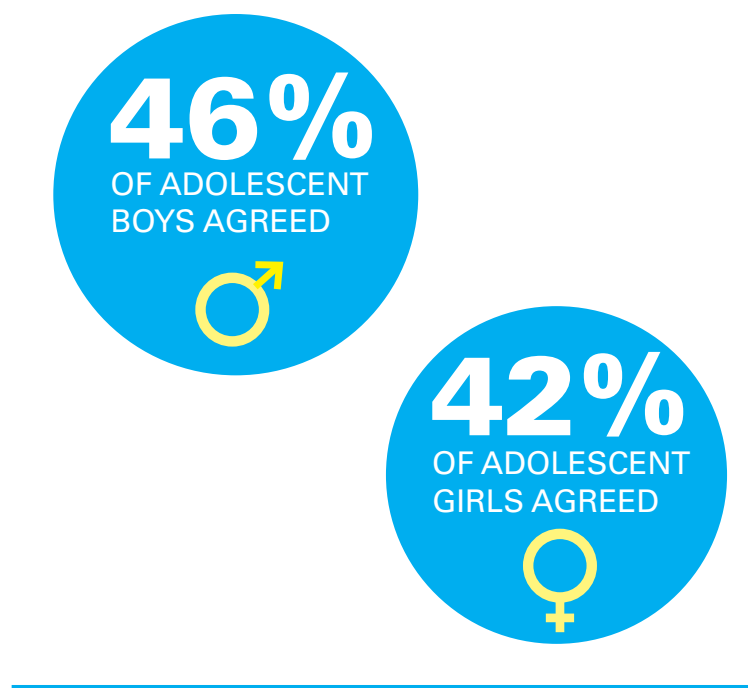




\section{Health and healthy behaviors}

ADOLESCENCE IS A PERIOD OF RAPID PHYSICAL AND EMOTIONAL GROWTH WITH INCREASED RISKS AND OPPORTUNITIES FOR PROMOTING HEALTHY BEHAVIORS.

(III) Adolescents are faced with a complex set of challenges related to puberty, sexuality, and their health. The ways in which they navigate behaviors, attitudes, and norms related to health and healthy behaviors have a direct impact on their well-being.

IIII) Appropriate support systems, effective programs and policies, and evidence-based decision-making are essential to facilitate healthier transitions to adulthood and to enable adolescents to lead healthy lives.

\section{PUBERTY AND NORIMS}

Our study shows that restrictions related to notions of pollution associated with menstruation have wide-ranging implications, particularly in the Mid and Far Western

region. Among all adolescent girls in this region:

- $95 \%$ responded that they were asked to observe some form of restriction during their first menstrual period.

- $44 \%$ respondents observed Chaupadi rituals at first menstruation and were isolated and confined to a shed outside their home.

- Almost $90 \%$ of girls knew about the menstrual cycle.

- $85 \%$ of girls reported that they use cotton cloth to manage their bleeding and don't have access to commercial sanitary products.

\section{SEXUAL INITIATION}

Sexual initiation occurs within marriage for girls but not for boys. For girls it occurs at an early age because marriage is early.

$14 \%$ of boys and $26 \%$ of girls aged $15-19$, mos of whom are married, reported ever having sexual intercourse. Among boys who had had sex, 56\% were married while among girls $99 \%$ were married.

Among those who had sex, the mean age at first sex was 15.7 years.

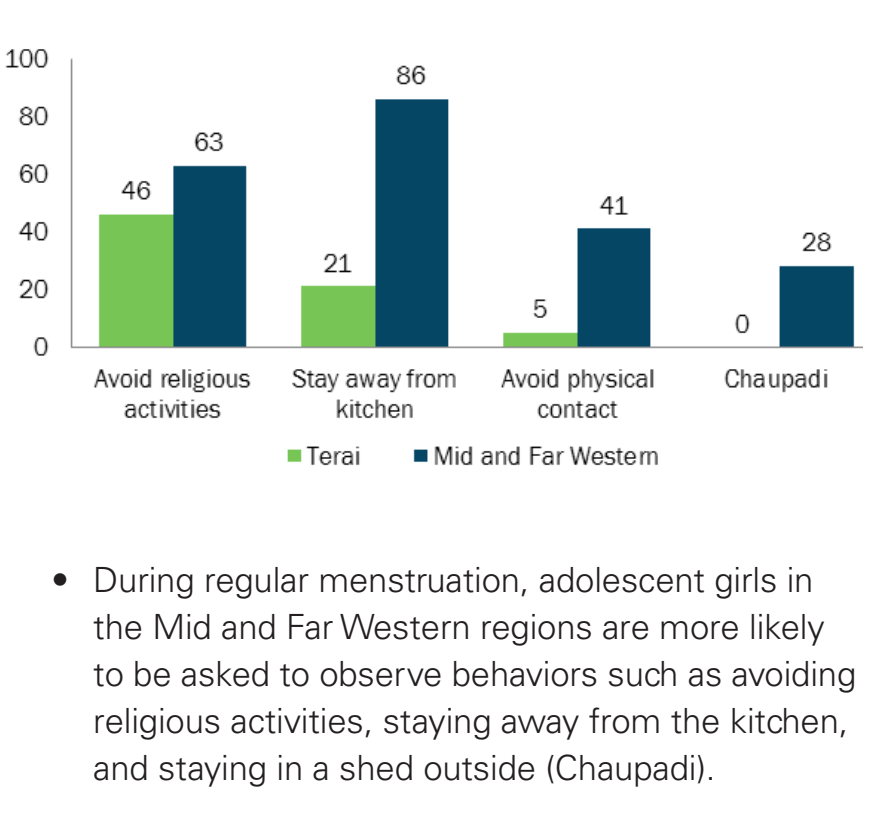

FAMIILY PLANNING

Although $86 \%$ of adolescents (aged 15-19) had heard of at least one modern method of contraception, most lack access to adequate family planning and contraceptives. Contraceptive use, particularly among those who have ever had sex, is low:

- $56 \%$ of all adolescents had ever used a method, although much of this is dominated by traditional methods such as withdrawal.

- $26 \%$ of 15-19 year olds who ever had sex had ever used a modern method of contraception. Boys reported almost double the rate of use compared to girls $(40 \%$ and $20 \%$, respectively).
CONTRACEPTIVE USE

Current use of modern methods is $19 \%$. Reported use is higher among boys ( $45 \%$ ) compared to girls (14\%).

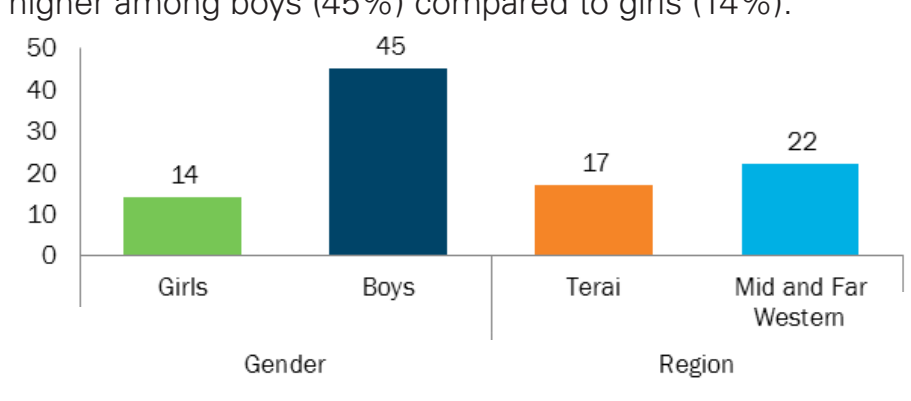

EARLY PREGNANCY

- $10 \%$ of all adolescent girls aged 15-19 have ever been pregnant (<1\% among never-married).

- Among those ever-married, however, $7 \%$ had a pregnancy by age 15 .

IIII) Median age at first pregnancy: $\mathbf{1 6 . 2}$ years.

- $38 \%$ of $15-19$ year old girls reported having a preference for a son.

- $71 \%$ of all 15-19 year olds had heard of abortion.

\section{MATERNAL HEALTH}

Among girls aged 15-19 who have ever been pregnant,

$55 \%$ had four or more antenatal care visits. But, $41 \%$

delivered their babies at home.

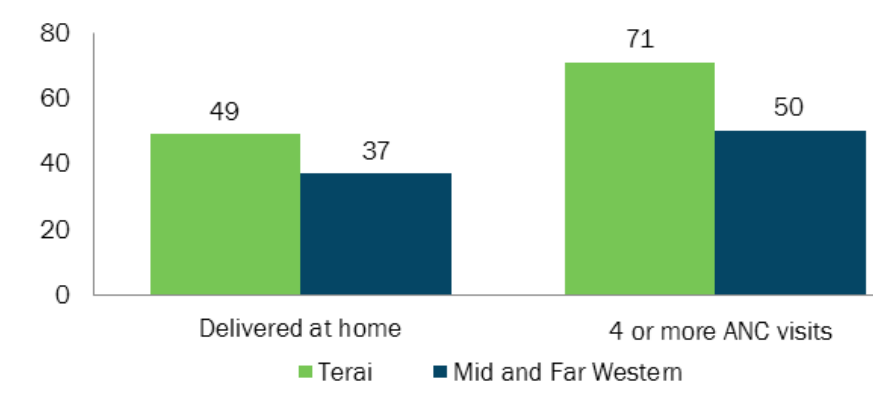

\section{CONCLUSION}

Adolescent health and healthy behavior is a vast area that covers a range of issues. Girls in Nepal face significant risks that arise from harmful social norms related to puberty, early marriage, early sexual initiation, pregnancy and childbearing, and elevated risks of STIs and HIV. In surveyed ADAP districts, which are among the nation's poorest-performing areas, these issues are particularly pronounced. A concerted programmatic and policy-based response that addresses specific patriach norns is needed to address issues retatspecific patiarch norms is needed to address issues related to health and heathy be navior. These changes are likely to take time to manifest, but interventions must start now.

\section{HIGHLIGHTS}

Challenges for adolescents, particularly girls, remain as they go through puberty. Particularly in the Mid and Far Western districts, harmful practices such as Chaupadi continue to dominate the experiences of girls as they go through this important physiological transition.

- Although sexual initiation occurs within marriage for most girls, early marriage results in early sexual initiation. Less than half of sexually active adolescents in ADAP study districts had ever used a contraceptive method. Only one in five reported currently using a modern method.

- Adolescents are aware of HIV but only one in four adolescents had correct knowledge of HIV transmission.

\section{HIV KNOWLEDGE}

Among 15-19 year olds, $70 \%$ had ever heard of HIV but only $23 \%$ had correct knowledge of transmission.

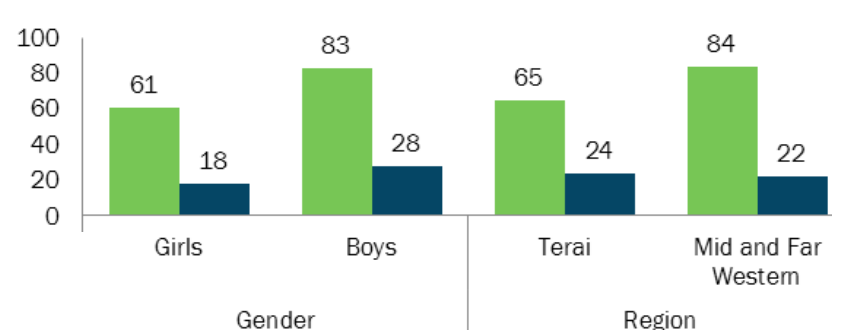

MAJOR ISSUES RAISED BY

ADOLESCENTS DURING PARTICIPATORY GROUP DISCUSSIONS

GIRLS

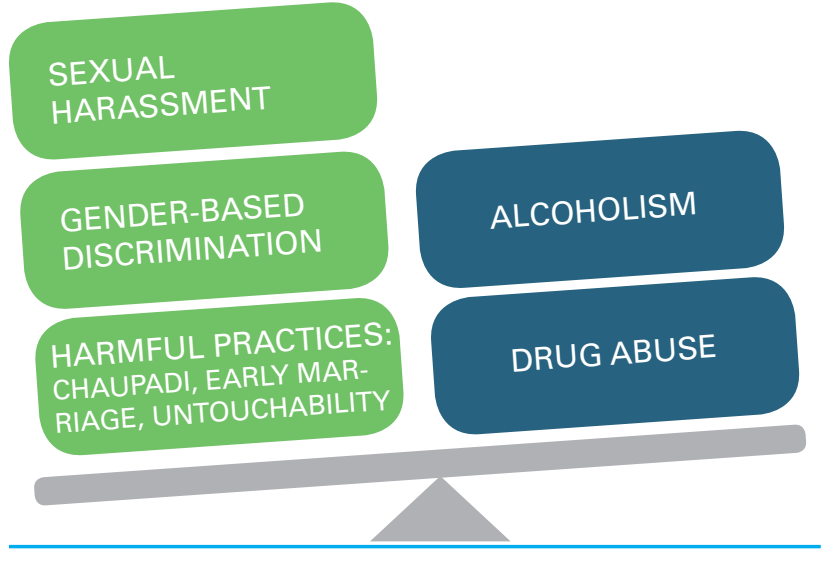




\section{Civic engagement and participation}

ADOLESCENTS NEEDTO BECOME FULLY FUNCTIONING MEMBERS OF SOCIETY. THEIR PARTICIPATION INTHE MATTERS THAT SHAPE THEIR LIVES IS

INSTRUMENTALTO ENHANCING THE QUALITY OF DECISIONS THAT ARE MADETO HELP THEM MAKE SMOOTHTRANSITIONS INTO ADULTHOOD.

IIII) Young people can be a part of decision-making processes by actively participating in various organizations such as child and youth clubs, community groups, women's and savings and credit groups, voluntary and political organizations.

IIII) Increasingly popular in Nepal, child clubs have emerged as important institutions to enhance the participation of children and youth in advocating for their rights and in democratic processes. Access to these clubs remains limited in our study districts.

ACCESS TO FACILITIES THAT ENABLE PARTICIPATION OF ADOLESCENTS IN COMIMUNITIES

Despite low participation levels in institutions such as clubs, adolescents in the 15 ADAP districts have relatively good access to institutions such as playgrounds, sports clubs and youth clubs.

Although variation by gender is relatively equitable, access in the Terai is seen to be substantially lower than in the Mid and Far Western region. Participation of adolescents in children's or youth clubs in the 15 UNICEF study districts is low. This is true across all age ranges and for both sexes and is particularly pronounced in the Terai, where only $3 \%$ of adolescents surveyed said that they were members of clubs, compared to $17 \%$ in the Far and Mid Western region.
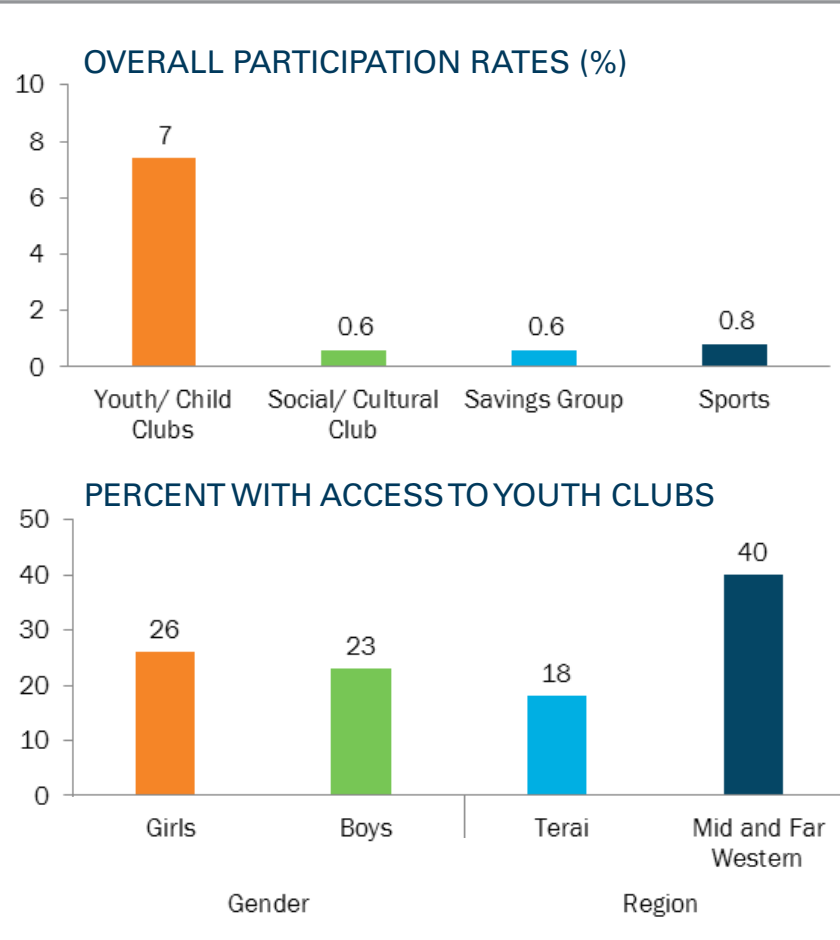

PARTICIPATION IN SELECTED INSTITUTIONS WHEN AVAILABLE

When adolescents had access to institutions, results show that young people had high levels of participation in most institutions such as youth clubs, sports clubs or libraries.

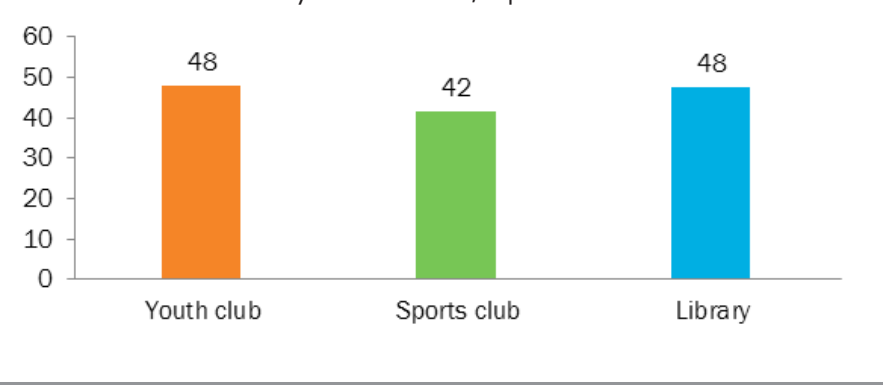

PARTICIPATION IN SELECTED INSTITUTIONS WHEN AVAILABLE BY REGION

Participation in youth clubs and libraries among adolescents to whom it was available was significantly higher in the Mid and Far Western ADAP districts compared to the Terai.

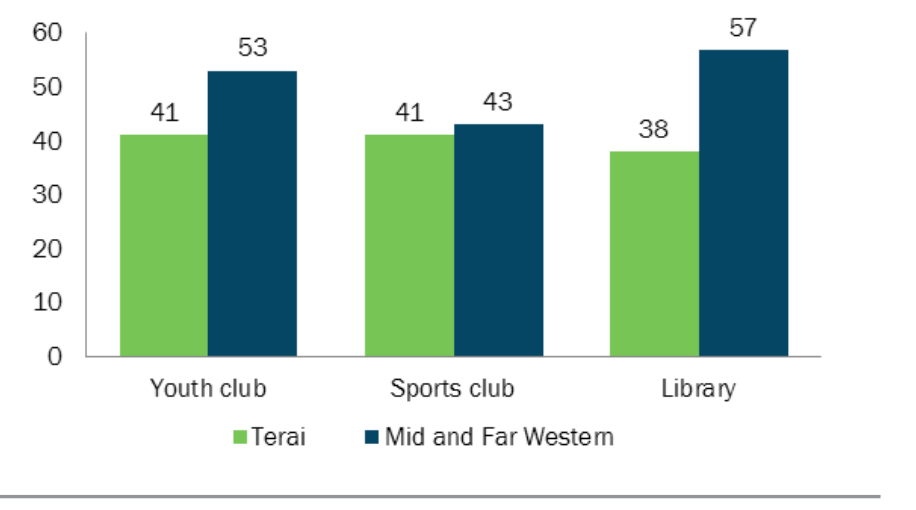

\section{CONCLUSION}

Young people and adolescents benefit from participation in institutions and groups in making successful transitions to adulthood. In the ADAP study districts, the participation rates are disproportionately low relative to the level of access perceived by adolescents. This shows that there is a mismatch between access and use. When available, adolescents participate enthusiastically.

Programmatic and policy responses should facilitate civic engagement and participation by young people not only by helping form institutions, clubs and groups, but by making participation much more accessible by facilitating

membership.

\section{HIGHLIGHTS}

- Multiple institutions facilitate participation of adolescents in important aspects of their lives to advocate for their rights.

- Adolescents want to be involved with insttutions such as clubs or informal groups. When they have access to them, they participate enthusiastically.

- Access to institutions such as youth and sports clubs, microfinance institutions, and vocational or livelihood institutions is very limited in the ADAP study districts and particularly so in the Terai districts.

- The most common forms of participation for adolescents for both genders are outdoor games and cultural events at school.

- Participation in higher decision-making bodies such as school management com mittees, Village Development Committees and health management committees for adolescents is non-existent in ADAP study districts.

PARTICIPATION IN ACTIVITIES INTHE PAST WEEK

Among All Adolescents in ADAP Districts

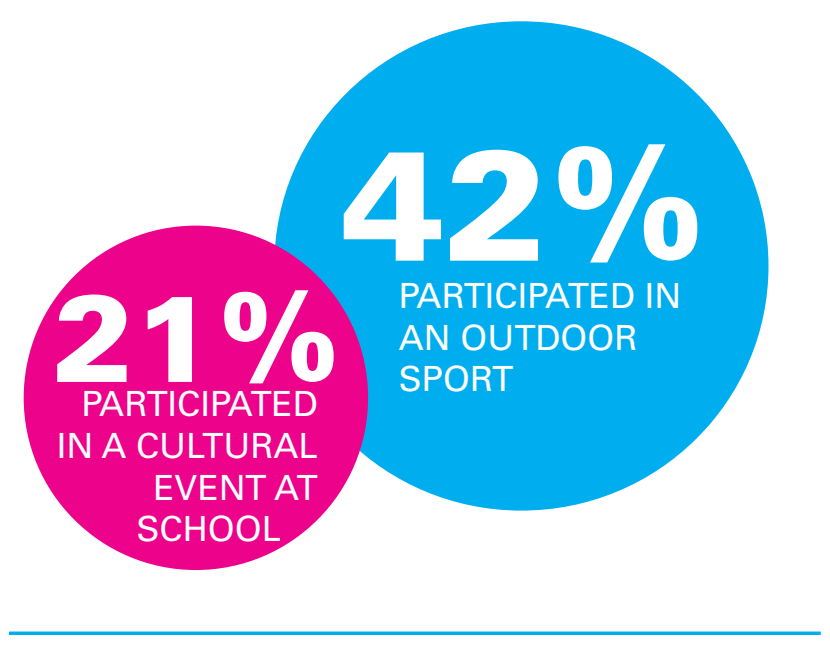

A CHILD ORYOUTH

CLUB (AMONG ALL

ADOLESCENTS IN 
United Nations Children's Fund (UNICEF)

Nepal Country Office

Adolescent Development and Participation Section

Pulchowk, Lalitpur

NEPAL

unicef.org/nepal

Population Council

One Dag Hammarskjold Plaza

New York, NY 10017

USA

popcouncil.org

\section{SUGGESTED READINGS}

“The Adolescent Experience In-Depth: Using Data to Identify and Reach the Most Vulnerable Young People: Nepal 2006." 2009. New York: Population Council.

Amin, Sajeda, Ashish Bajracharya, Michelle Chau, and Mahesh Puri. Forthcoming. “UNICEF Adolescent

Development and Participation Baseline Report." New York: Population Council.

\section{CITATION}

Amin, Sajeda, Ashish Bajracharya, Michelle Chau, and Mahesh Puri. 2014. "Highlights from the UNICEF Adolescent Development and Participation Baseline Study." New York: Population Council.

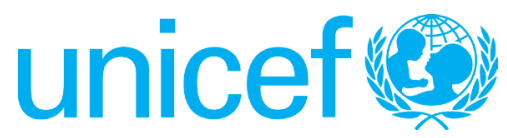

